Article

\title{
Crosstalk between Human Microvascular Endothelial Cells and Tubular Epithelial Cells Modulates Pro-Inflammatory Responses Induced by Shiga Toxin Type 2 and Subtilase Cytotoxin
}

\author{
Romina S. Álvarez ${ }^{1}$, Carolina Jancic ${ }^{2,3}$, Nicolás Garimano ${ }^{1}$, Flavia Sacerdoti ${ }^{1}$, \\ Adrienne W. Paton ${ }^{4}$, James C. Paton ${ }^{4}$, Cristina Ibarra ${ }^{1}$ and María M. Amaral ${ }^{1, *}$ \\ 1 Laboratorio de Fisiopatogenia, Departamento de Fisiología, Instituto de Fisiología y Biofísica Bernardo \\ Houssay (IFIBIO Houssay-CONICET), Facultad de Medicina, Universidad de Buenos Aires, \\ Buenos Aires 1121, Argentina; roalvarez_4@yahoo.com.ar (R.S.Á.); garimano@gmail.com (N.G.); \\ flasacerdoti@gmail.com (F.S.); cristinaadrianaibarra@gmail.com (C.I.) \\ 2 Laboratorio de Inmunidad Innata, Instituto de Medicina Experimental (IMEX-CONICET), \\ Academia Nacional de Medicina, Buenos Aires 1425, Argentina; cjancic@hotmail.com \\ 3 Departamento de Microbiología, Parasitología e Inmunología, Facultad de Medicina, Universidad de \\ Buenos Aires, Buenos Aires 1121, Argentina \\ 4 Research Centre for Infectious Diseases, Department of Molecular and Biomedical Science, University of \\ Adelaide, Adelaide 5005, Australia; adrienne.paton@adelaide.edu.au (A.W.P.); \\ james.paton@adelaide.edu.au (J.C.P.) \\ * Correspondence: mmamaral74@gmail.com
}

Received: 11 October 2019; Accepted: 5 November 2019; Published: 7 November 2019 updates

\begin{abstract}
Hemolytic uremic syndrome (HUS) is a consequence of Shiga toxin (Stx)-producing Escherichia coli (STEC) infection and is the most frequent cause of acute renal failure (ARF) in children. Subtilase cytotoxin (SubAB) has also been associated with HUS pathogenesis. We previously reported that Stx2 and SubAB cause different effects on co-cultures of human renal microvascular endothelial cells (HGEC) and human proximal tubular epithelial cells (HK-2) relative to HGEC and HK-2 monocultures. In this work we have analyzed the secretion of pro-inflammatory cytokines by co-cultures compared to monocultures exposed or not to Stx2, SubAB, and Stx2+SubAB. Under basal conditions, IL-6, IL-8 and TNF- $\alpha$ secretion was different between monocultures and co-cultures. After toxin treatments, high concentrations of Stx2 and SubAB decreased cytokine secretion by HGEC monocultures, but in contrast, low toxin concentrations increased their release. Toxins did not modulate the cytokine secretion by HK-2 monocultures, but increased their release in the HK-2 co-culture compartment. In addition, HK-2 monocultures were stimulated to release IL-8 after incubation with HGEC conditioned media. Finally, Stx2 and SubAB were detected in HGEC and HK-2 cells from the co-cultures. This work describes, for the first time, the inflammatory responses induced by Stx 2 and SubAB, in a crosstalk model of renal endothelial and epithelial cells.
\end{abstract}

Keywords: Shiga toxin; Subtilase cytotoxin; Hemolytic Uremic Syndrome; endothelial/epithelial human renal cells; co-cultures; cytokines

Key Contribution: Endothelial-epithelial communication contributes to the inflammatory response induced by the action of Stx2 and SubAB toxins on renal cells. Cytokines released from endothelial cells can stimulate epithelial cells to release IL-6, IL-8 and TNF- $\alpha$. 


\section{Introduction}

Hemolytic uremic syndrome is clinically characterized by thrombocytopenia, non-immune hemolytic anemia, and acute renal failure (ARF) [1]. The most frequent presentation of HUS is the infection by Shiga toxin (Stx)-producing Escherichia coli (STEC) [2]. HUS is widely distributed throughout the world and studies about the global incidence of human STEC infections and deaths estimated that STEC causes more than 2.8 million acute illnesses annually, leading to 3,890 cases of HUS, 270 cases of end-stage renal disease and 230 deaths [3]. STEC O157:H7 has been the most frequent serotype associated with large outbreaks or sporadic cases of hemorrhagic colitis and HUS cases, although non-O157 serotypes have been increasingly reported to account for HUS [4]. Like in many parts of the world, in the southern countries of the continent (Argentina, Chile, Uruguay) STEC O157:H7 is associated with a significant number of HUS cases [5]. In Argentina, Stx-associated HUS is endemic and around the last 10 years, approximately 400 new cases were reported annually [6]. The incidence ranges since 10 to 17 cases per 100,000 children under 5 years of age, and the lethality is between 1 and 4\% [7]. HUS is extremely prevalent in Argentina, being the most frequent cause of ARF and the second most important cause of chronic renal failure (CRF) in the pediatric age [8,9].

STEC O157:H7 and non-O157:H7 strains carry inducible lambda phages integrated into their genomes and can be transmitted between related bacteria [10]. The toxin genes are transcribed only during the lytic stage of the phage. The production of Stx is linked to the replication cycle of Stx phages, and the release of Stx is dependent on the lytic phase, which is induced under stress conditions [11]. The phages encode two types of Stx, Stx1 and Stx2. Stx2 presents several different variants (Stx2a to Stx2g), which have high homology (93-100\%), except for Stx2f variant (69\% identity) [12]. Furthermore, two additional Stx2 types, Stx2h and Stx2i, were recently described [13,14]. STEC strains encoding Stx2 are more frequently related to the most severe cases of HUS [15] and the subtype Stx2a cause more serious illnesses than strains encoding Stx2c [16].

Humans be able to be infected by STEC as a result of ingestion of raw meat, unpasteurized dairy products, contaminated water and vegetables, or direct contact with farm animals [17]. In addition, humans can become infected by transmission from person to person through the fecal-oral route [6]. This last infection pathway has become more prevalent in recent years and is favored by the low infective dose of STEC ( $<100$ bacteria). The possibilities of infection are associated with biological and cultural causes of the host, reservoirs and microorganism characteristics [18].

After infection, bacteria colonize the intestine and release Stx inside the lumen. Following this, Stx can access the systemic blood circulation and then contact the principal target cells by binding to the globotriaosylceramide (Gb3) receptor $[19,20]$. Stx is then internalized, by receptor mediated endocytosis and causes cell damage by the inhibition of protein synthesis and the induction of cell stress response pathways which finally unchains apoptosis [21].

Subtilase cytotoxin (SubAB) has also been associated with HUS pathogenesis as it was identified, in Australia, in a STEC strain belonging to the O113:H21 serotype, responsible for an outbreak [22] and it also was detected in isolates from bloody diarrhea HUS and diarrhea and household HUS contact in Argentina [23]. This cytotoxin damages cells through proteolytic cleavage of the endoplasmic reticulum chaperone BIP (GRP78) [24] and consequently, activates a massive ER (endoplasmic reticulum) stress response that finally ends in apoptosis [25-27]. To date, SubAB has not been detected yet in patients, but several serotypes of STEC expressing SubAB have been associated to HUS cases around the world [23]. Injection of purified SubAB has also been shown to stimulate the hallmark symptoms of HUS in mice [28].

SubAB binds $\alpha$-2-3-linked $N$-glycolylneuraminic acid (Neu5Gc) through its pentameric B-subunit [22,29] and these Neu5Gc terminating glycans are not expressed on healthy tissues of humans [30]. However, these receptors can be incorporated by ingestion of red meat as well as dairy products [31].

So far, it is not well known how SubAB contributes to HUS pathophysiology; however, it was proposed that it is able to increase the clinical features of STEC infection [32]. 
It is well established that the kidney is seriously affected in Stx-associated HUS, because of the presence of especially Stx-sensitive cells that express high amounts of Gb3 receptor [33]. The thrombotic microangiopathy lesion is the typical injury caused by Stx in the kidney as a consequence of the direct action of Stx on glomerular endothelial cells and tubular epithelial cells by activating cellular death by apoptosis. In addition, Stx also can induce the release of pro-inflammatory cytokines, leukocyte recruitment, platelet aggregation and fibrin deposition. These events lead to partial or complete vessel occlusion by microthrombi and the consequent microangiopathic hemolytic anemia. Exeni et al. had postulated that inflammation could contribute to the endothelial damage [34]. Finally, kidney injury is expressed as different degrees of renal failure [35].

Most studies related to the Stx2 and SubAB effects in the kidney have employed renal endothelial and epithelial cell monocultures. However, the crosstalk established in vivo between these types of cells has not been considered. Accordingly, it has been postulated that the injury of renal tubules observed in patients with HUS is induced by the damage caused to the glomerular filtration barrier and enhanced by a direct action of Stx 2 on the tubules [36,37]. In the kidney, proximal tubular cells and microvascular endothelial cells, both sensitive to Stx 2 and SubAB [38,39], cooperate to regulate the hemodynamic and tubular function [40]. In this sense, we have previously developed a crosstalk model of human renal microvascular endothelial cells (HGEC) with human proximal tubular epithelial cells (HK-2) that attempted to simulate in vitro the physiological function of the human renal proximal tubule. In this crosstalk model, we found that Stx 2 and SubAB cause different effects on cell viability and water absorption properties of HGEC/HK-2 co-cultures respect to HGEC and HK-2 monocultures. Contrary to the effects seen in monocultures, toxins did not cause inhibitory effects on water absorption across HGEC/HK-2 co-cultures and in addition, Stx 2 cytotoxic effects on the monocultures' viability were attenuated [39]. Considering these observations, we can speculate that soluble mediators secreted from endothelial and/or epithelial cells might be involved in these differential toxin effects. So, the purpose of this work was to analyze the response of pro-inflammatory cytokines released by HGEC and HK-2 monocultures compared to HGEC/HK-2 co-cultures exposed to Stx2 and SubAB, and try to shed light on the role of soluble mediators in regulating damage induced by Stx and/or SubAB in the kidney.

\section{Results}

2.1. Monocultures and Co-Cultures Exhibit Differential Secretion of Interleukin (IL)-6, Interleukin (IL-8) and Tumor Necrosis Factor (TNF)- $\alpha$ under Basal Conditions

We evaluated the secretion of IL-6, IL- 8 and TNF- $\alpha$ in HGEC and HK-2 monoculture supernatants and HGEC/HK-2 co-culture total supernatant, under basal conditions. We found that HGEC monocultures released a higher IL-6 and IL-8 concentration compared to HK-2 monocultures and HGEC/HK-2 co-cultures. In addition, the secretion of these cytokines by HGEC/HK-2 was also significantly higher compared to HK-2 (Figure 1A,B). On the contrary, HGEC/HK-2 co-cultures did not show any significant differences in TNF- $\alpha$ secretion compared to HGEC and HK-2 (Figure 1C). We then analyzed the secretion of IL-6, IL- 8 and TNF- $\alpha$ by co-cultures, but quantifying cytokine production in each compartment, and compared these results to those obtained in HGEC and HK-2 monocultures. Figure 1D,E show that IL-6 and IL-8 secretion was higher in HGEC monocultures compared to the level observed on the HGEC side of co-cultures. Furthermore, while IL-8 release was higher on the HK-2 side of the co-culture relative to HK-2 monocultures (Figure 1E), non-significant differences were observed in IL-6 secretion (Figure 1D). Finally, TNF- $\alpha$ release did not show any significant differences between HGEC and HK-2 co-culture compartments compared to monocultures (Figure 1F). 
A
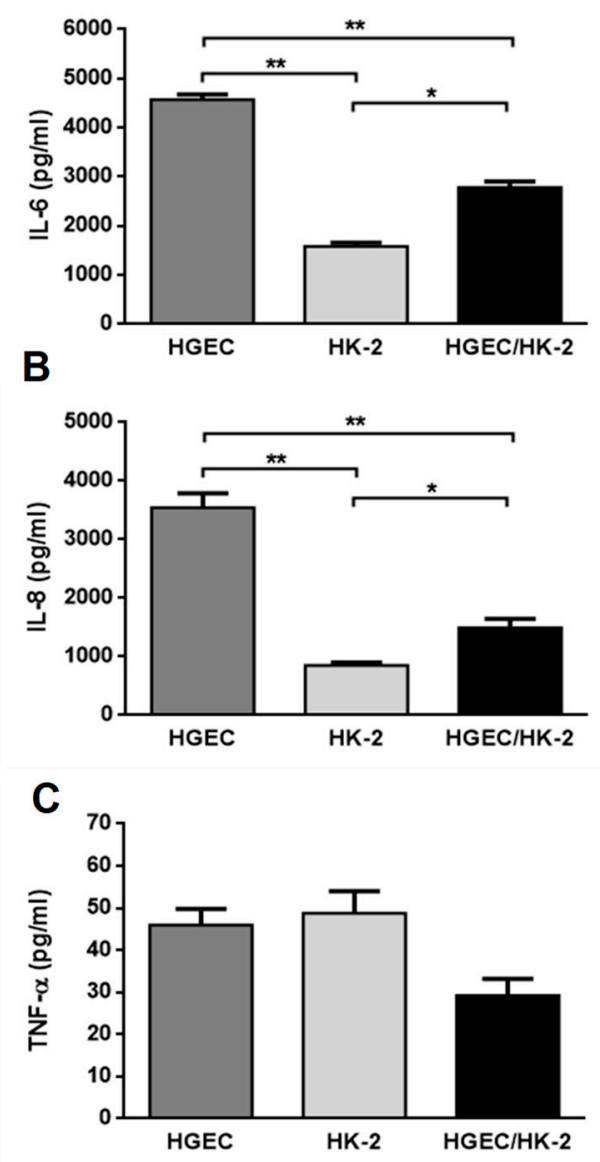

D

E
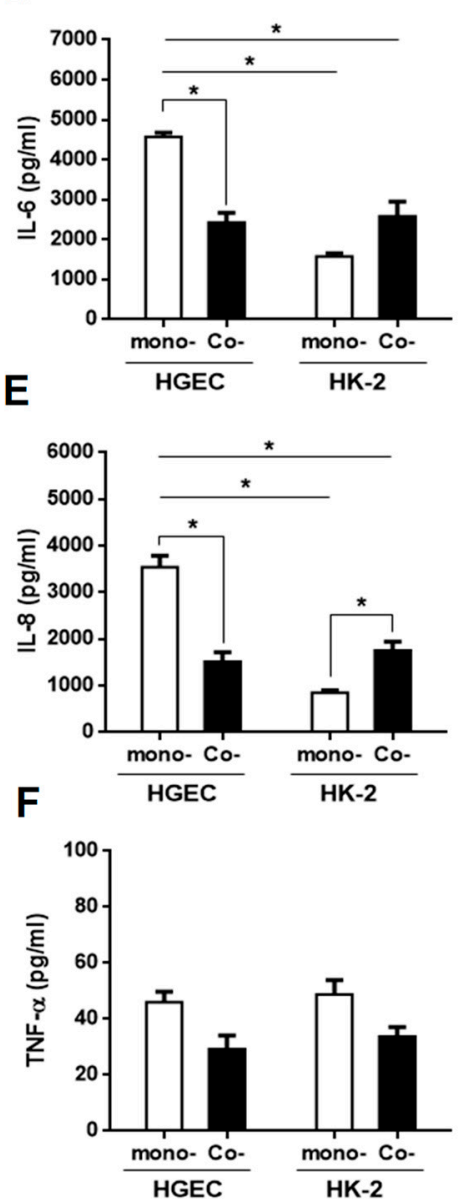

Figure 1. Cytokines secreted under basal conditions by HGEC and HK-2 monocultures and HGEC/HK-2 co-cultures. Basal levels of IL-6 (A), IL-8 (B) and TNF- $\alpha$ (C) secreted in supernatants of HGEC and HK-2 monocultures or in total supernatant of HGEC/HK-2 co-cultures were quantified by ELISA. Comparison are shown between IL-6 (D), IL-8 (E) and TNF- $\alpha$ (F) levels secreted by monocultures (mono-) of HGEC or HK-2 and HGEC or HK-2 co-culture compartments (Co-). Results are expressed as mean \pm SEM of four experiments. HGEC vs. HK-2 vs. HGEC/HK-2 and HGEC or HK-2 co- vs. HGEC or HK-2 mono-, $(n=4) .{ }^{*} p<0.05,{ }^{* *} p<0.01$.

2.2. Stx2 and SubAB Induce Changes in the Release of Pro-Inflammatory Mediators by HGEC and HK-2 Monocultures

To investigate the effect of Stx2 and SubAB on the production of pro-inflammatory cytokines by renal endothelial and epithelial cells, we first analyzed the secretion of IL-6, IL- 8 and TNF- $\alpha$ by monocultures of HGEC and HK-2 after $24 \mathrm{~h}$ of treatment with different concentrations of Stx2, SubAB or Stx2+SubAB. We observed that high concentrations of Stx2 $(10 \mathrm{ng} / \mathrm{mL})$, SubAB $(100$ and $1000 \mathrm{ng} / \mathrm{mL})$ and co-incubation with both toxins induced a significant decrease in the secretion of IL-6 and IL-8 by HGEC (Figure 2A,B). Likewise, when we analyzed the secretion of these cytokines by stimulated HK-2 cells, we observed a similar effect to that found in HGEC (Figure 3A,B). In addition, Stx2 (1 and $10 \mathrm{ng} / \mathrm{mL}$ ), SubAB (100 and $1000 \mathrm{ng} / \mathrm{mL}$ ) and co-incubation with both toxins, were able to reduce the cell viability of HGEC (Figure 2D) and HK-2 (Figure 3D). In contrast to previous results, the lowest Stx 2 concentrations used $(0.001-1 \mathrm{ng} / \mathrm{mL})$ increased the secretion of IL-6, IL- 8 and TNF- $\alpha$ by HGEC; and SubAB at $1000 \mathrm{ng} / \mathrm{mL}$ or co-incubation with Stx2 + SubAB $(0.01 \mathrm{ng} / \mathrm{mL}+1 \mathrm{ng} / \mathrm{mL}$; $0.1 \mathrm{ng} / \mathrm{mL}+10 \mathrm{ng} / \mathrm{mL}$ ) increased the secretion of TNF- $\alpha$ (Figure 2A-C). HK-2 cells only showed 
inhibitory effects of the toxins on the IL-6 and IL- 8 secretion or no effect on the release of TNF- $\alpha$ (Figure 3A-C).

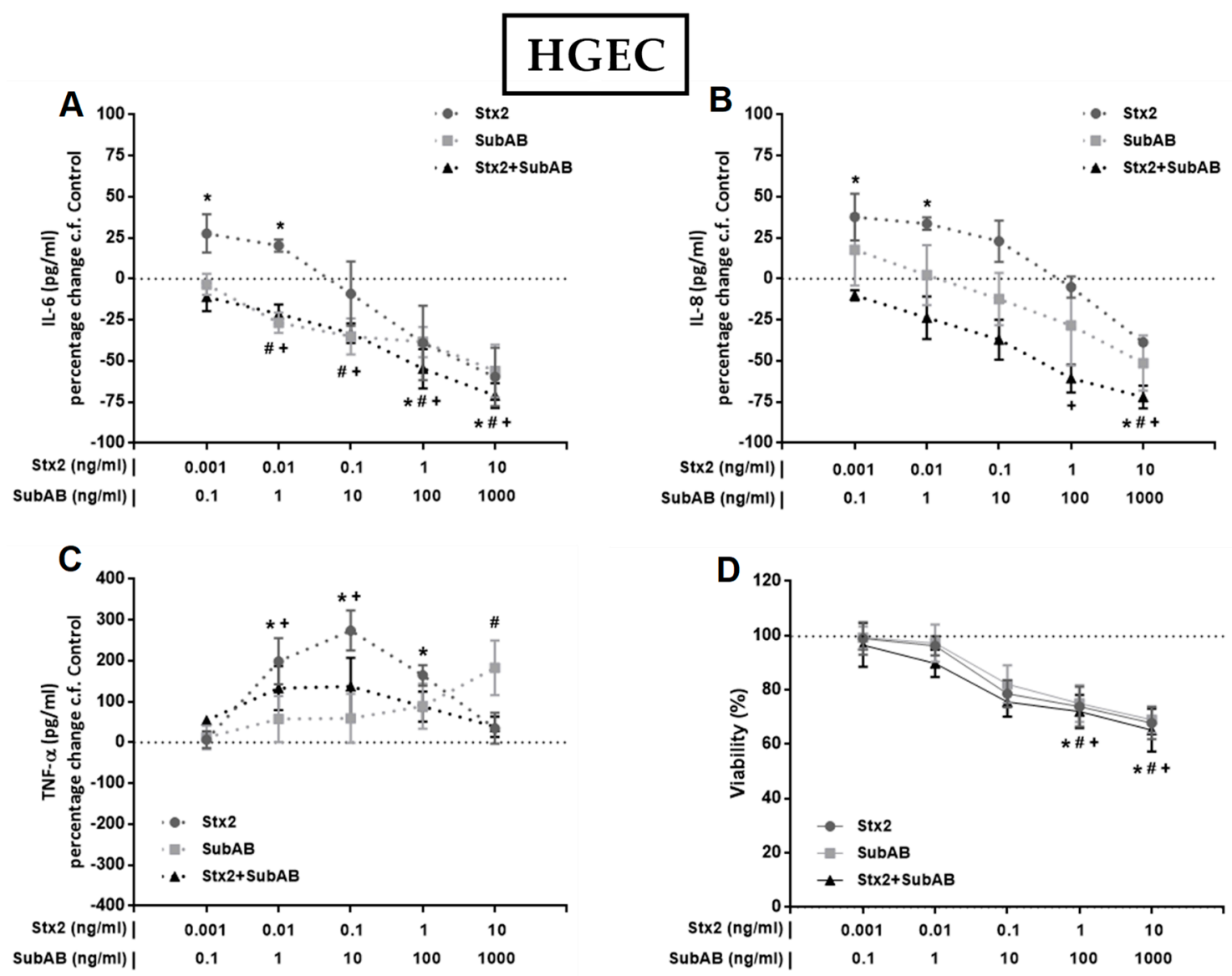

Figure 2. Effects of Stx2, SubAB and Stx2+SubAB on cytokine secretion and cell viability of HGEC monocultures. HGEC monocultures were treated with different concentrations of Stx2, SubAB and Stx2+SubAB for $24 \mathrm{~h}$ and IL-6 (A), IL-8 (B) and TNF- $\alpha$ (C) were quantified by ELISA. Results are expressed as the percentage $(\%)$ change in $\mathrm{pg} / \mathrm{mL}$ relative to basal cytokine levels (control) (percentage change c.f Control). In addition, cell viability was analyzed by neutral red uptake (D). Absorbance was read at $540 \mathrm{~nm}$ and $100 \%$ was considered the viability of cells incubated under the same conditions but without toxin treatment (control). Results are expressed as mean \pm SEM of three experiments. Ctrl vs. *Stx2, "SubAB or ${ }^{+}$Stx2+SubAB. $p<0.05$. 


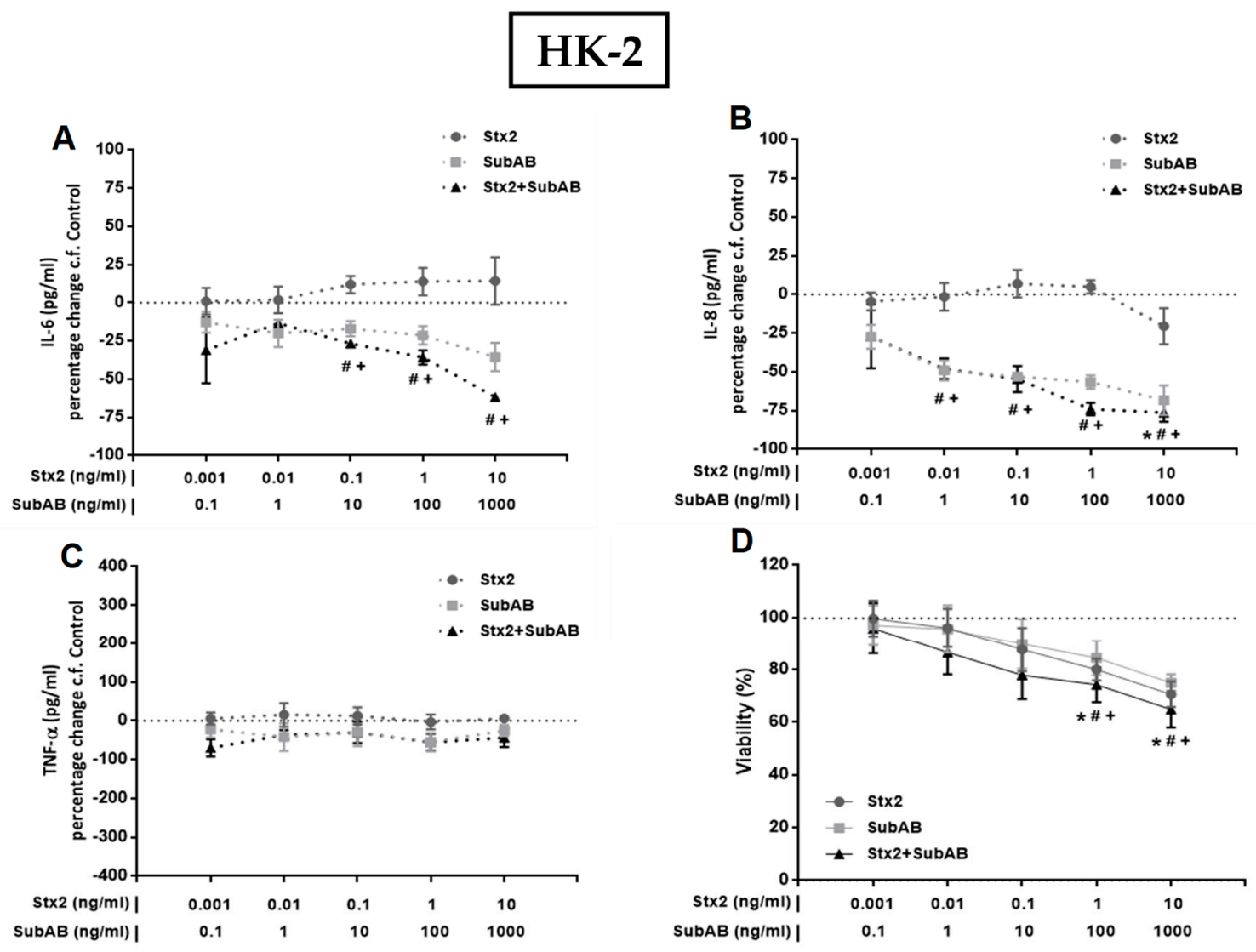

Figure 3. Effects of Stx2, SubAB and Stx2+SubAB on cytokine secretion and cell viability of HK-2 monocultures. HK-2 monocultures were treated to different concentrations of Stx 2, SubAB and Stx2+SubAB for $24 \mathrm{~h}$ and IL-6 (A), IL-8 (B) and TNF- $\alpha$ (C) were quantified by ELISA. Results are expressed as the percentage (\%) change in $\mathrm{pg} / \mathrm{mL}$ relative to basal cytokine levels (control) (percentage change c.f Control). In addition, cell viability was analyzed by neutral red uptake (D). Absorbance was read at $540 \mathrm{~nm}$ and $100 \%$ was considered the viability of cells incubated under the same conditions but without toxin treatment (control). Results are expressed as mean \pm SEM of three experiments. Ctrl vs. *Stx2, "SubAB or +Stx2+SubAB. $p<0.05$.

\subsection{Stx2 and SubAB Exhibit Differential Effects on IL-6, IL-8 and TNF- $\alpha$ Secretion by Monocultures and Co-Cultures}

Next, we evaluated the secretion of IL-6, IL-8 and TNF- $\alpha$ in HGEC and HK-2 monocultures and HGEC/HK-2 co-cultures after exposure to Stx2 (0.01 ng/mL), SubAB (1 ng/mL) or Stx2+SubAB, added into the HGEC compartment. We selected the toxin concentrations that did not affect HGEC and HK-2 cell viability and that were able to stimulate cytokine secretion by HGEC. After $24 \mathrm{~h}$ of incubation, all treatments increased the secretion of IL-6, IL- 8 and TNF- $\alpha$ by co-cultures relative to controls (Figure 4A-C). In addition, when we compared the release of IL-6 in monocultures with co-culture compartments, we found that Stx2 increased IL-6 in the HGEC side similarly to that observed in HGEC monocultures (Figure 4D). On the other hand, SubAB and Stx2+SubAB did not induce any significant change in the secretion of IL- 6 in the HGEC compartment with respect to untreated cells. Unlike in HGEC monocultures, a significant decrease in the concentration of IL- 6 was observed (Figure 4A,D). When the HK-2 compartment was compared to HK-2 monocultures, we observed that Stx2, SubAB and Stx2+SubAB did not modify the concentration of IL-6 in HK-2 monocultures (Figure 4A,D); in contrast, the toxins induced a significant increase of this cytokine production in HK-2 compartment of co-cultures (Figure 4D). Finally, in co-cultures, the IL-6 concentration exhibited significant differences for SubAB and Stx2+SubAB treatments between the endothelial and epithelial compartments (Figure 4D). 


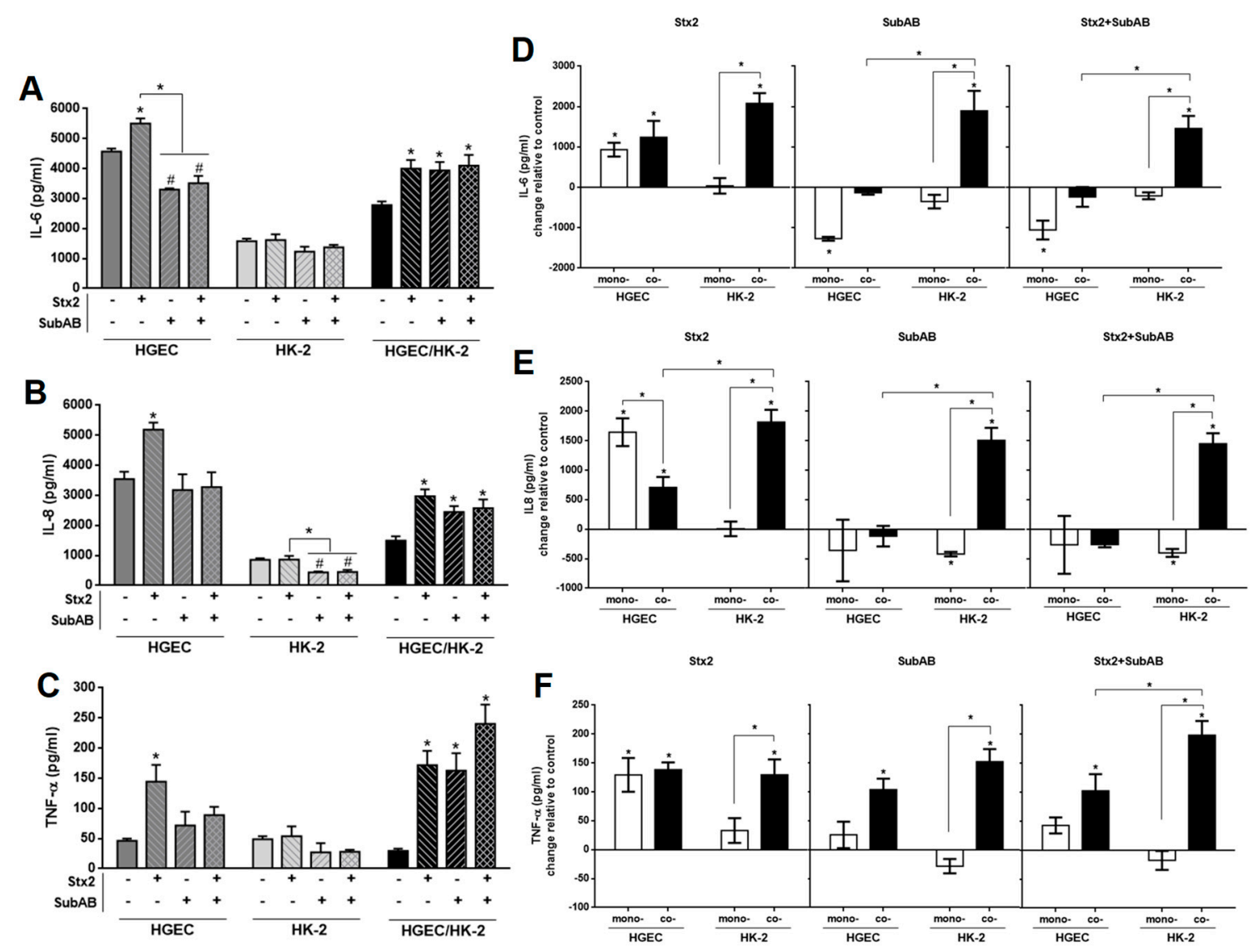

Figure 4. Differential effects on IL-6, IL- 8 and TNF- $\alpha$ secretion by monocultures and co-cultures exposed to Stx2, SubAB and Stx2+SubAB. HGEC, HK-2 monocultures and HGEC/HK-2 co-cultures were exposed to Stx2 (0.01 ng/mL), SubAB (1 ng/mL) or Stx2+SubAB $(0.01 \mathrm{ng} / \mathrm{mL}+1 \mathrm{ng} / \mathrm{mL})$ for $24 \mathrm{~h}$. IL-6 (A), IL-8 (B) and TNF- $\alpha$ (C) secreted in supernatants of HGEC and HK-2 monocultures or in total supernatant of HGEC/HK-2 co-cultures were quantified by ELISA. Comparison between IL-6 (D), IL-8 (E) and TNF- $\alpha$ (F) levels secreted by monocultures (mono-) of HGEC or HK-2 and HGEC or HK-2 co-culture compartments (Co-). Results are expressed as mean \pm SEM of four experiments. HGEC vs. HK-2 vs. HGEC/HK-2 and HGEC or HK-2 co- vs. HGEC or HK-2 mono-, $(n=4) .{ }^{*} p<0.05$.

On the other hand, Stx 2 caused a significant increase in IL-8 production in the HGEC compartment when cultured together with HK-2 and in HGEC monocultures relative to controls (Figure 4B,E). Interestingly, the IL-8 concentration was higher in HGEC monocultures than in the HGEC compartment when co-cultured with HK-2 cells (Figure 4E). In addition, non-significant differences were observed in SubAB and Stx2+SubAB treatments (Figure 4B,E). In relation to epithelial cells, Stx2, SubAB and Stx2+SubAB significantly increased IL-8 in the HK-2 compartment of co-cultures compared to controls and also to HK-2 monocultures (Figure 4E). Moreover, a decrease in IL-8 secretion was observed in HK-2 monocultures by SubAB and Stx2+SubAB and non-significant changes were detected for Stx2 treatment (Figure 4B,E).

Moreover, TNF- $\alpha$ secretion was significantly increased by Stx2, SubAB and Stx $2+$ SubAB treatments in the endothelial and epithelial co-culture compartments compared to controls (Figure 4F). We found that Stx 2 increased TNF- $\alpha$ in the HGEC compartment similarly to that observed in HGEC monocultures (Figure 4F). Furthermore, a significant increase in TNF- $\alpha$ secretion by Stx2, SubAB and Stx2+SubAB was observed in the HK-2 compartment with respect to HK-2 monocultures, where no modulation had been detected after treatment with the toxins (Figure $4 \mathrm{C}, \mathrm{F}$ ). Similar results were obtained when comparing the release of TNF- $\alpha$ in the HGEC compartment relative to HGEC monocultures after SubAB and Stx2+SubAB treatment (Figure $4 \mathrm{~F}$ ). 


\subsection{Soluble Mediators Released by HGEC Increase the Secretion of IL-8 by HK-2}

Taking into account the results obtained regarding the differential secretion of cytokines induced by toxins in the HK-2 co-culture compartment compared to HK-2 monocultures, we hypothesize that soluble factors secreted by HGEC in the co-culture could stimulate the secretion of IL-6, IL- 8 and TNF- $\alpha$ by HK-2. As shown in Figure 5, the conditioned medium (CM) derived from HGEC control, Stx2, SubAB and Stx $2+$ SubAB treatments were able to augment the secretion of IL- 8 by HK- 2 monocultures. In addition, a significant increase was observed when cells were stimulated with CM from HGEC treated with Stx2+SubAB relative to CM of control HGEC. Furthermore, when Brefeldin A (BF) was incorporated to HK-2 monocultures after the addition of HGEC CM, a blockage of IL-8 secretion by HK-2 monocultures was obtained for all treatments (Figure 5). On the contrary, we did not observe any modulation for IL-6 and TNF- $\alpha$ secretion (data not shown).

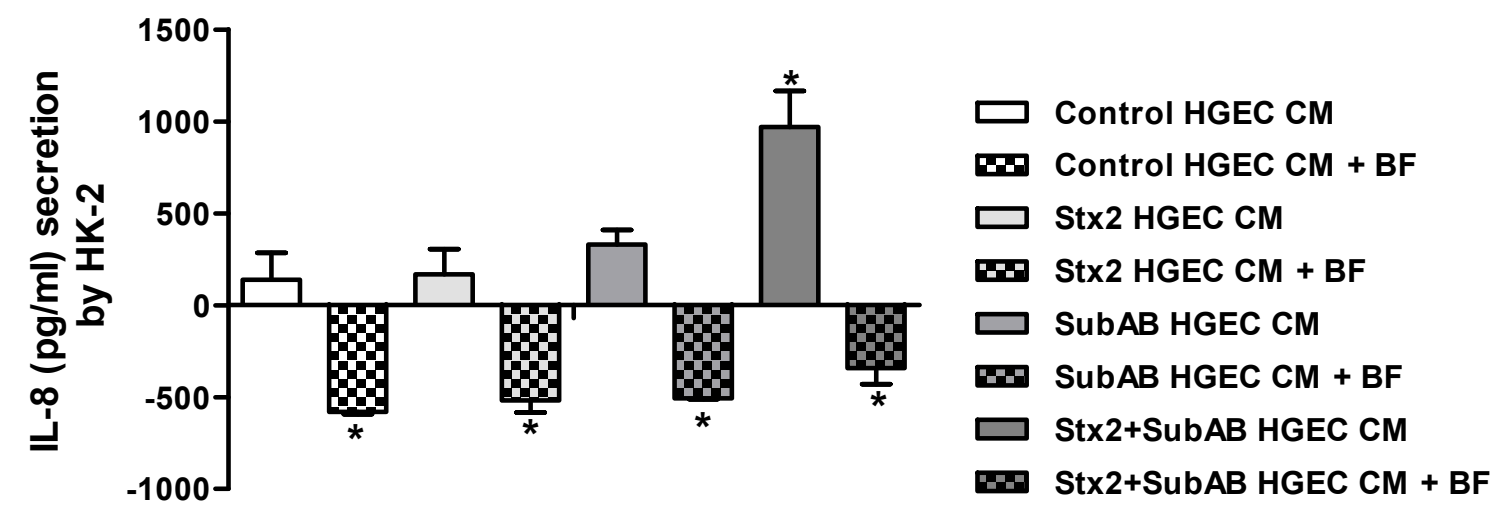

Figure 5. IL-8 secretion by HK-2 cells exposed to HGEC conditioned media. HK-2 cells were incubated during $24 \mathrm{~h}$ with CM of HGEC previously treated or not with Stx2 $(0.01 \mathrm{ng} / \mathrm{mL})$, SubAB $(1 \mathrm{ng} / \mathrm{mL})$ or Stx2+SubAB $(0.01 \mathrm{ng} / \mathrm{mL}+1 \mathrm{ng} / \mathrm{mL})$ for $24 \mathrm{~h}$ and in presence or not of BF. IL-8 concentration was quantified by ELISA. IL- 8 concentration $=($ IL- 8 concentration in the supernatant of HK-2 after each treatment) - (basal IL-8 concentration in the supernatant of control HK-2) - (IL-8 concentration in the $\mathrm{CM}$ of control or treated HGEC). Results are expressed as mean \pm SEM of three experiments. Ctrl vs. Stx2, SubAB or Stx $2+$ SubAB and Ctrl or treatments vs. Ctrl or treatments $+\mathrm{BF},{ }^{*} p<0.05$.

\subsection{Toxins Were Incorporated by HGEC and HK-2 Cells Derived from Co-Cultures}

Finally, we analyzed the presence of Stx2 and SubAB in HGEC and HK-2 cells recovered from the two different sides of the co-culture. In the HGEC co-culture compartment, Stx2 was detected in about $48 \%$ of HGEC cells, SubAB in $63 \%$ and both toxins in $68 \%$ (Figure $6 \mathrm{~A}$, Table 1 ). In addition, in the HK-2 co-culture compartment, Stx 2 was detected in around $35 \%$ of HK-2 cells, SubAB in $32 \%$ and both toxins in $41 \%$ (Figure $6 \mathrm{~B}$, Table 2). 
A
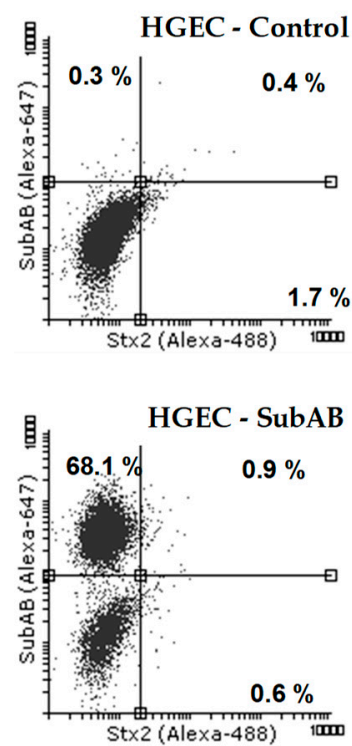
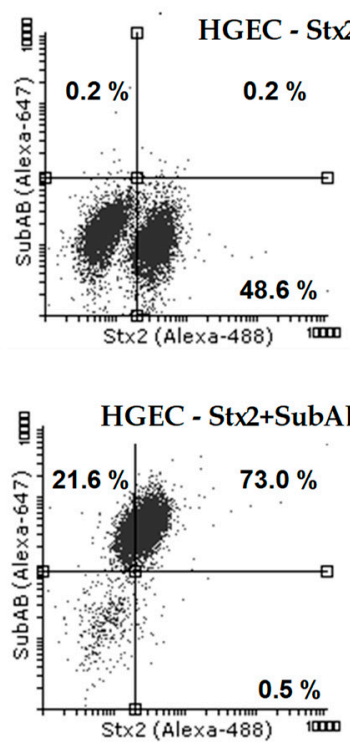

B
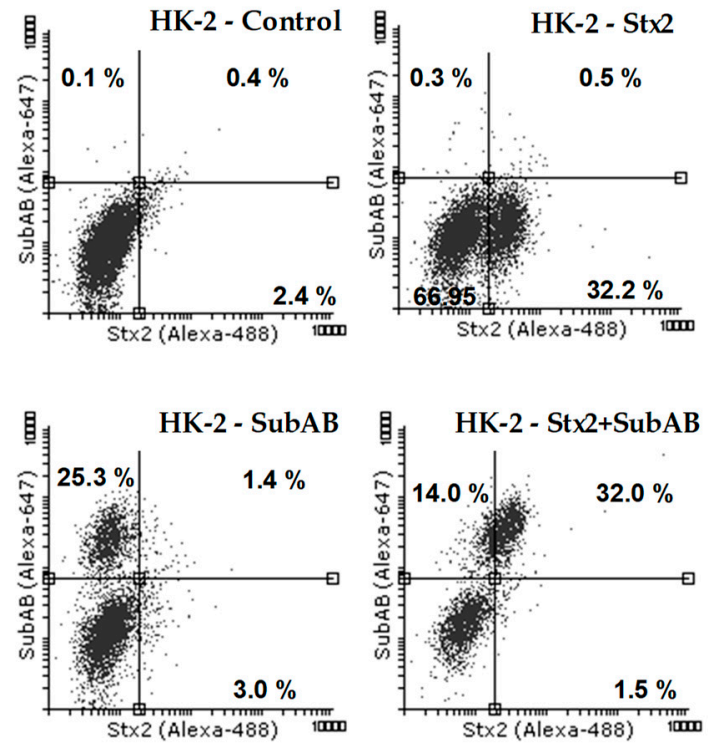

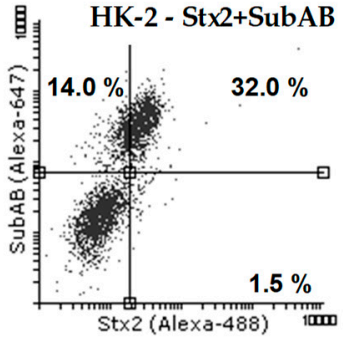

Figure 6. Internalization of Stx2, SubAB or both toxins by HGEC and HK-2 in co-culture. HGEC/HK-2 co-cultures were exposed or not to Stx2 $(0.01 \mathrm{ng} / \mathrm{mL})$, SubAB $(1 \mathrm{ng} / \mathrm{mL})$ or Stx $2+\operatorname{SubAB}(0.01 \mathrm{ng} / \mathrm{mL}$ $+1 \mathrm{ng} / \mathrm{mL}$ ) for $24 \mathrm{~h}$. Then HGEC and HK-2 cells were removed from the cell culture inserts and the presence of Stx2, SubAB and Stx2+SubAB were evaluated by HGEC and HK-2 intracellular staining and flow cytometry analysis. Stx 2 was detected by a mouse anti-Stx 2 and then with an anti-mouse Dylight 488-conjugated antibody. SubAB was identified by a rabbit anti-SubAB and then with an anti-rabbit Alexa Fluor 647-conjugated antibody. The results are expressed as the percentage of positive cells for Stx2, SubAB and Stx2+SubAB. Representative dot plots are shown for HGEC (A) and HK-2 (B).

Table 1. HGEC co-culture compartment. Positive cells for Stx2, SubAB and Stx2+SubAB, means \pm SEM, $n=3$. Ctrl vs. Stx2, SubAB or Stx $2+\operatorname{SubAB}, * p<0.05$.

\begin{tabular}{ccccccccc}
\hline \multirow{2}{*}{ HGEC } & \multicolumn{2}{c}{ Control } & \multicolumn{2}{c}{ Stx2 } & \multicolumn{2}{c}{ SubAB } & \multicolumn{2}{c}{ Stx2+SubAB } \\
\cline { 2 - 9 } & $\%$ & SEM & $\%$ & SEM & $\%$ & SEM & $\%$ & SEM \\
\hline Stx2 + & 1.5 & 1.2 & $48.4^{*}$ & 8.5 & 0.7 & 0.4 & 0.9 & 0.4 \\
\hline SubAB + & 0.2 & 0.1 & 0.9 & 1.3 & $62.6^{*}$ & 7.5 & $20.3^{*}$ & 4.1 \\
\hline Stx2 - SubAB + & 0.3 & 0.1 & 0.3 & 0.2 & 0.7 & 0.6 & $68.3^{*}$ & 4.2 \\
\hline
\end{tabular}

Table 2. HK-2 co-culture compartment. Positive cells for Stx2, SubAB and Stx2 + SubAB, means \pm SEM, $n=3$. Ctrl vs. Stx2, SubAB or Stx $2+\operatorname{SubAB}, * p<0.05$.

\begin{tabular}{ccccccccc}
\hline \multirow{2}{*}{ HK-2 } & \multicolumn{2}{c}{ Control } & \multicolumn{2}{c}{ Stx2 } & \multicolumn{2}{c}{ SubAB } & \multicolumn{2}{c}{ Stx2+SubAB } \\
\cline { 2 - 10 } & $\%$ & SEM & $\%$ & SEM & $\%$ & SEM & $\%$ & SEM \\
\hline Stx2 + & 1.8 & 1.1 & $35.0 *$ & 4.1 & 1.9 & 0.9 & 4.9 & 6.6 \\
\hline SubAB + & 0.3 & 0.1 & 3.8 & 4.4 & $31.8 *$ & 5.9 & $12.5^{*}$ & 2.0 \\
\hline Stx2 - SubAB + & 0.4 & 0.1 & 0.8 & 0.4 & 0.9 & 0.4 & $40.6^{*}$ & 15.3 \\
\hline
\end{tabular}

\section{Discussion}

STEC strains are recognized by their ability to cause severe disease in humans, like HUS. Pianciola \& Rivas [4] have reported the incidence of STEC O157 infections and HUS cases in different countries. These data show that Argentina exhibits the highest prevalence of HUS in the world, probably related to high circulation of hypervirulent clade 8 strains $[41,42]$. 
This pathology cannot be easily prevented and to date, there is no authorized vaccine or effective therapy is available for humans. Therefore, extension of our knowledge about Stx2 and SubAB action and their deleterious effects in the kidneys, is critical to find a strategy to control this disease. Previously, we have developed an in vitro human proximal tubule model. In this model we had shown that Stx2 and SubAB effects were attenuated when endothelial and epithelial renal cells were cultured in a very close proximity, unlike in isolated endothelial and epithelial monocultures [39]. Therefore, we proposed that these differential effects could be due to a special microenvironment containing soluble factors produced during the communication between microvascular endothelial cells and proximal tubular cells. Furthermore, in recent years, several studies in both in vitro and in vivo models have demonstrated the activation of an inflammatory response that favors the cytokines secretion, the kidney leukocytes recruitment and the activation of coagulation and complement cascades during the development of HUS. In this sense, patients with Stx-associated HUS have shown immunological parameters that are indicative of an inflammatory state [34]. Taking into account the importance of the inflammatory microenvironment in HUS, in this work we analyzed the secretion of selected pro-inflammatory mediators released by HGEC/HK-2 co-cultures and HGEC and HK-2 monocultures, at basal conditions and after treatment with Stx2, SubAB or with both toxins together (Stx2 + SubAB).

Our results showed that cytokine secretion, in basal conditions, depends on the type of cells and whether those cells were cultured as monocultures or cocultures. The basal concentration of IL- 6 has been reported in two different models of co-culture and in correlation with our results, a difference in IL- 6 concentration was observed between monocultures and co-cultures. In these studies, no additive effect of microvascular endothelial cells and tubular epithelial cells was found for the secretion of IL-6 $[43,44]$.

We studied cytokine secretion in monocultures and showed that high concentrations of Stx2, SubAB or Stx2+SubAB decreased IL- 6 and IL-8 secretion by HGEC monocultures and reduced the cell viability, as we had previously reported [38,39]. Nevertheless, low concentrations of Stx2 that have no effect on cell viability, induced an increase in the secretion of these cytokines. In addition, both toxins individually or co-incubated, also increased the secretion of TNF- $\alpha$.

Our results obtained in HGEC monocultures are in accordance with those previously reported in other models. In this regard, we can mention that Stx induced the up regulation of IL-8, IL-6, MCP-1 and GM-CSF in several endothelial cell lines, at concentrations that are non-inhibitory for protein synthesis and non-cytotoxic in terms of cell viability [45-50]. MCP-1 and IL-8 were up regulated by Stx 2 in glomerular endothelial cells [46]. In addition, Stx2 induced the released of IL-8, Regulated upon Activation, Normal T cell Expressed, and Secreted (RANTES), Stromal Cell-Derived Factor 1 alpha $($ SDF- $1 \alpha)$, and Stromal Cell-Derived Factor 1 beta (SDF-1 $\beta$ ) by the microvascular endothelial cell line HMEC-1 [45].

In relation to SubAB, and similar to our results, Wang et al. showed that SubAB decreased the secretion of IL- 8 and MCP-1 in a colonic epithelial cell line (HCT-8) and in brain microvascular endothelial cells (HBMEC); in this latter cell line they also observed a reduction in IL-6 release. Additionally, they found a discrepancy between mRNA and protein levels suggesting that the destruction of BiP by SubAB action caused a disruption of ER function that compromises cytokine export [50].

Regarding the co-incubation of both toxins together (Stx2 + SubAB), there is very little information available. It has been reported by Wang et al. that the treatment of the human macrophage U937 cell line with both toxins together avoided the stimulatory effect of Stx2 on the secretion of IL-8 [50]. This observation is in agreement with our results obtained in HGEC monocultures, in which we observed that while Stx 2 stimulated the IL-8 release, co-incubation with both toxins had no effect or even decreased their production. Therefore, in accordance with these results, SubAB could modulate the inflammatory response induced by Stx2. Contrary to HGEC monocultures, we found that Stx2 did not modulate the release of any of these pro-inflammatory cytokines by HK-2 monocultures. SubAB and the co-incubation with Stx2 decreased IL-6 and IL-8 secretion, but had no effect on the release of 
TNF- $\alpha$. In this regard, Lentz et al. demonstrated that HK-2 cells treated with Stx1 and Stx2 increased the TNF- $\alpha$ and IL-1 mRNA levels without a simultaneous increase in expression of the respective protein [51].

In this work, we used SubAB concentrations two orders of magnitude higher than those of Stx2. We have previously demonstrated that different concentrations of Stx2 and SubAB are required to obtain similar HGEC and HK-2 cell damage effects [38,39]. Taking into account these observations, we can speculate that the higher concentrations of SubAB, when compared to Stx2, required to elicit cell damage is probably due to the low abundance of Neu5Gc-terminating receptor structures in HGEC and HK-2, although we can't exclude their incorporation from the FCS in the medium.

On the other hand, co-cultures incubated with Stx2, SubAB, or both toxins, showed an increase in cytokines secretion. So, co-cultures treated with these toxins showed the opposite effect with respect to HGEC monocultures where we found that SubAB and both toxins did not stimulate or suppress IL-6, IL-8 and TNF- $\alpha$ release.

A lower concentration of IL-6 and IL-8 was observed in the endothelial compartment of the co-culture compared to HGEC monocultures, under basal conditions. Previous reports suggested that differences may be related to the activation of primary cultures of microvascular endothelial cells when they are cultured as monolayers [52] and a special microenvironment generated in the co-cultures could be responsible for decreasing the basal endothelial activation $[43,53]$.

Surprisingly, after incorporation of Stx2, SubAB and both toxins on the co-culture endothelial side, a significant increase of IL-6, IL-8 and TNF- $\alpha$ was observed on the epithelial (HK-2) side compared to HK-2 monocultures. Taking this into account, we could hypothesize that in this co-culture model, when toxins are incorporated on the endothelial side, they stimulate the release of IL-6, IL- 8 and TNF- $\alpha$ in both endothelial and epithelial compartments. In addition, a greater increase of these cytokines was evident in the epithelial compartment of the co-culture relative to the endothelial compartment, as well as in comparison with the HGEC and HK-2 monocultures. In this sense, Bijuklic et al. demonstrated in a co-culture model that after treatment with LPS, an increase of IL-8 and IL-6 in the epithelial side was observed, without changes in the endothelial side [44].

To clarify this point, we studied if soluble mediators released by HGEC monocultures that had been incubated or not with toxins, could stimulate HK-2 monocultures for the secretion of cytokines. We found that HK-2 monocultures released a higher concentration of IL-8 after treatment with CM of HGEC and this effect was more pronounced after treatment with CM of HGEC previously incubated with both toxins. In addition, we corroborated that this cytokine had been produced by HK-2 cells according to Brefeldin A treatment. Taking into account that HK-2 cells express TNF- $\alpha$ receptors [54], in our co-culture model, we can speculate that the epithelial cells could produce inflammatory mediators as a consequence of sensing TNF- $\alpha$ released by HGEC cells.

Interestingly, Stx 2 and SubAB were detected in HGEC and HK-2 cells after co-culture. Importantly, the presence of each toxin in the HK-2 cells was observed even though they were not incubated in direct contact with Stx2 and SubAB and, no decrease in the cell viability was observed. It is possible that the access of Stx2 and SubAB from the HGEC compartment to the HK-2 compartment is favored by changes in the endothelial paracellular pathway as a result of the secretion of some cytokines. In this regard, previous reports on human lung microvascular endothelial cells show that TNF- $\alpha$ promotes the opening of endothelial intercellular gaps. $[55,56]$. Furthermore, after treatment with Stx2+SubAB, most of cells were positive for both toxins. Taking into account that Stx2 and SubAB have different receptors, both located in the cell membrane within specific domains [57], it is possible to speculate that the interaction of one toxin with its receptor facilitates the binding of the other toxin to its own, e.g., by upregulation of the cognate glycans. To clarify this point, further studies will be necessary.

In summary, we demonstrate that endothelial-epithelial communication contributes to the inflammatory response stimulated by the action of Stx 2 and SubAB toxins on renal cells. In this sense, we propose that after STEC infection, toxins can access the blood stream and bind the endothelial cells and also the epithelial cells. When high toxin concentrations are circulating, they cause direct cell 
damage in renal epithelial and endothelial cells that should be attenuated due to the close-proximity between these cells, as we previously showed in vitro [39]. However, when low toxin concentrations are circulating, they do not cause direct cell damage or a decrease in the cell viability, but Stx2 may induce the release of soluble pro-inflammatory mediators such as IL-6, IL- 8 and TNF- $\alpha$ by endothelial cells. In addition, the very close proximity between the endothelial and epithelial cells could allow TNF- $\alpha$ released from endothelial cells to stimulate epithelial cells to release IL-6, IL- 8 and TNF- $\alpha$, thereby amplifying the inflammatory process in the proximal tubule.

\section{Conclusions}

Data from this work describe, for the first time, the inflammatory response stimulated by Stx2 and SubAB in a co-culture model of human renal endothelial and epithelial cells. This inflammatory response could contribute to the initial events of ARF observed in patients with HUS.

\section{Materials and Methods}

\subsection{Reagents}

Purified Stx2a was provided by Phoenix Laboratory, Tufts Medical Center, Boston, MA, USA. Lipopolysaccharide (LPS) content on Stx2 was checked by Limulus amebocyte lysate (LAL) test $(<10 \mathrm{pg} / \mathrm{mL})$. SubAB was purified from recombinant $E$. coli by Ni-NTA chromatography via a $\mathrm{His}_{6}$ tag fused to the C-terminus of the B subunit, as described previously [22]. Purity was greater than $98 \%$, as judged by SDS-PAGE and staining with Coomassie Blue.

\subsection{Antibodies}

Mouse monoclonal antibody 2E11 against the A-subunit of Stx2 was kindly provided by Dr. Roxane M. F. Piazza [58]. Rabbit anti-SubA has been described previously [59]. Anti-mouse Dylight 488-conjugated and anti-rabbit Alexa Fluor 647-conjugated antibodies were purchased from Invitrogen (ThermoFisher Scientific, Buenos Aires, Argentina); rabbit anti-VWF was from DAKO (Tecnolab, Buenos Aires, Argentina); mouse anti-CD31 (PECAM-1) -FITC was from Sigma Aldrich.

\subsection{Human Primary Glomerular Microvascular Endothelial Cell Culture}

Human glomerular endothelial cells (HGEC) were isolated from kidney fragments removed from normal areas from different pediatric patients with segmental uropathies or tumors in one pole and normal creatinine that were undergoing nephrectomies performed at Hospital Nacional "Alejandro Posadas", Buenos Aires, Argentina (written informed consent was obtained from the next of kin, caretakers, or guardians on the behalf of the minors/children participants involved in our study, $\mathrm{n}^{\circ}: 035$ LUP1So/17 (13)). The Ethics Committee of the University of Buenos Aires approved the use of human renal tissues for research purposes. Endothelial cells were isolated as was previously described [38]. Once isolated, cells were grown in M199 media supplemented with 20\% fetal calf serum (FCS), $3.2 \mathrm{mM}$ L-glutamine, $100 \mathrm{U} / \mathrm{mL}$ penicillin/streptomycin (GIBCO, Waltham, MA, USA) and $25 \mu \mathrm{g} / \mathrm{mL}$ endothelial cell growth supplement (ECGS, Sigma, St. Louis, MO, USA) as previously reported [38]. For growth-arrested conditions, a medium with a half of FCS concentration $(10 \%)$ and without ECGS was used. For the experiments, cells were used between 2-7 passages, after characterization for von Willebrand factor and platelet/endothelial cell adhesion molecule 1 (PECAM-1) positive expression [38].

\subsection{Tubular Human Epithelial Cell Line Culture}

Human proximal tubular epithelial cell line (HK-2) was purchased from American Type Culture Collection (ATCC, Manassas, VA, USA) and grown in DMEM/F12 medium (Sigma Aldrich, St. Louis, MO, USA) containing 10\% FCS, $100 \mathrm{U} / \mathrm{mL}$ penicillin/streptomycin (GIBCO, Waltham, MA, USA), $2 \mathrm{mM}$ L-glutamine (GIBCO, Waltham, MA, USA), $15 \mathrm{mM}$ HEPES at $37^{\circ} \mathrm{C}$ in a humidified $5 \% \mathrm{CO}_{2}$ incubator. For growth-arrested conditions, medium without FCS was used. 


\subsection{Monocultures and Co-Cultures of Renal Endothelial and Epithelial Cells}

Co-cultures of HGEC and HK-2 cells were performed using Millicell cell culture inserts (PIHP01250, Millipore, Billerica, MA, USA). HGEC cells $\left(5.10^{4}\right)$ were seeded on the lower side of the filter $(0.4 \mu \mathrm{m}$ membrane pore size) and allowed to attach for 12-16 h. Then, inserts were inverted and HK-2 $\left(7.10^{4}\right)$ cells were seeded into the upper side. Co-cultures were maintained in HGEC complete medium. For the epithelial and endothelial monocultures, the same procedure was carried out with the exception that partner cells were not added [39]. To evaluate the effects of Stx2 and SubAB on monocultures and co-cultures, Stx 2 or SubAB were added to the lower compartment (HGEC compartment).

\subsection{Integrity of Endothelial and Epithelial Monolayers and Bilayers}

The integrity of endothelial and epithelial monolayers and bilayers was checked by using a Millicell-ERS electric resistance system (Millipore, Billerica, MA, USA) calibrated for each measurement, as previously described [39]. For that, the electrical resistance (TEER) was monitored daily during the development of cell culture until confluence was achieved. At this time, TEER values were stabilized, indicating that HGEC and HK-2 monolayers and HGEC/HK-2 bilayers had reached confluence.

\subsection{Cytokine Detection by ELISA}

Basal levels of IL-6, IL-8 and TNF- $\alpha$ cytokine secretion were measured in HGEC, HK-2 monoculture and co-culture supernatants. Cytokines released in co-cultures were quantified in the total supernatant (HGEC+HK-2 supernatants) and in the HGEC and HK-2 co-culture compartment supernatants, separately. Monocultures of HGEC and HK-2 were incubated or not during $24 \mathrm{~h}$ with different concentrations of Stx2 (0.001-10 ng/mL) or SubAB (0.1-1000 ng/mL) or both Stx2 + SubAB. For controls, growth-arrested conditioned medium was used.

For comparisons between monocultures and co-culture regarding pro-inflammatory cytokine secretion after toxin treatment, Stx2 $(0.01 \mathrm{ng} / \mathrm{mL})$, SubAB $(1 \mathrm{ng} / \mathrm{mL})$ or Stx2 $(0.01 \mathrm{ng} / \mathrm{mL})+$ SubAB $(1 \mathrm{ng} / \mathrm{mL})$ were employed.

Cell culture supernatants were collected and IL-6, IL- 8 and TNF- $\alpha$ were quantified by ELISA, according to the manufacturer's recommendations. Human IL-6, IL-8 and TNF- $\alpha$ ELISA kits were from BD Bioscience (San Diego, CA, USA).

For analyzing the effects of conditioned media [54] of HGEC on HK-2 cell secretion of IL-6, IL-8 and TNF- $\alpha$, HGEC monocultures were treated or not with Stx2 $(0.01 \mathrm{ng} / \mathrm{mL})$, SubAB $(1 \mathrm{ng} / \mathrm{mL})$ or Stx2 $(0.01 \mathrm{ng} / \mathrm{mL})+\operatorname{SubAB}(1 \mathrm{ng} / \mathrm{mL})$ during $24 \mathrm{~h}$, then CM was collected and employed to incubate HK-2 cells with them for $24 \mathrm{~h}$. In addition, Brefeldin A was incorporated or not for blocking the HK-2 cells ER to Golgi transport, $1 \mathrm{~h}$ after HGEC CM incubation to estimate the contribution of HK-2 on cytokine release. The concentration of cytokines secreted by HK-2 monocultures after exposure to HGEC CM was calculated as follows: (cytokine concentration in the HK-2 supernatant after each treatment)-(basal cytokine concentration in the control HK-2 supernatant)-(cytokine concentration in the CM of control or treated HGEC). Results are expressed as cytokine concentration in $\mathrm{pg} / \mathrm{mL}$.

\subsection{Cell Viability Evaluation}

To evaluate the Stx2 and SubAB effect on the cell viability, the neutral red cytotoxicity assay was adapted from previously described protocols [60]. Briefly, HGEC and HK-2 monocultures were treated or not during $24 \mathrm{~h}$ with Stx2 $(0.001-10 \mathrm{ng} / \mathrm{mL})$ or SubAB $(0.1-1000 \mathrm{ng} / \mathrm{mL})$ or both Stx2 + SubAB, in growth arrested conditions. After treatment, freshly diluted neutral red $(10 \mu \mathrm{g} / \mathrm{mL}$, Sigma Aldrich, St. Louis, MO, USA) was added to a final concentration of $10 \mu \mathrm{g} / \mathrm{mL}$ and cells were incubated for an additional $1 \mathrm{~h}$ at $37^{\circ} \mathrm{C}$ in $5 \% \mathrm{CO}_{2}$. Cells were then washed and fixed with $200 \mu \mathrm{L} 1 \% \mathrm{CaCl}_{2}+1 \%$ formaldehyde and then lysed with $200 \mu \mathrm{L} \mathrm{1 \%}$ acetic acid in 50\% ethanol to solubilize the neutral red. Absorbance in each well was measured in an automated plate spectrophotometer at $540 \mathrm{~nm}$. Results 
were expressed as percentage of cell viability, where $100 \%$ represents cells incubated under identical conditions but without toxins.

\subsection{Intracellular Detection of Stx2 and SubAB by Flow Cytometry in HGEC/HK-2 Co-Cultures}

The presence of Stx 2 and SubAB incorporated by the cells was evaluated in HGEC and HK-2 co-culture compartments by flow cytometry. For that, after treatment, cells were fixed in 1\% paraformaldehyde and permeabilized with $0.1 \%$ saponin in phosphate-buffered saline (PBS). Then, cells were incubated in PBS $0.5 \%$ FCS with mouse anti-Stx 2 for $2 \mathrm{~h}$ and then with a secondary anti-mouse Dylight 488-conjugated antibody for $1 \mathrm{~h}$, or incubated with rabbit anti-SubAB for $2 \mathrm{~h}$ and then with a secondary anti-rabbit Alexa Fluor 647-conjugated antibody for $1 \mathrm{~h}$. Cells were subsequently washed twice and resuspended in PBS. The staining was analyzed by flow cytometry on PARTEC PAS III using Flowing software 2.5.1.

\subsection{Data Analysis}

Data are presented as mean \pm SEM. Statistical analysis was performed using Graph Pad Prism Software 5.0 (San Diego, CA, USA). ANOVA was used to calculate differences between groups and Tukey's multiple comparisons test was used a posteriori. Statistical significance was set at $p<0.05$.

Author Contributions: Conceptualization: R.S.Á., C.J., C.I. and M.M.A. Formal analysis: R.S.Á., C.J., N.G., F.S., C.I., and M.M.A. Funding acquisition: C.I. and M.M.A. Investigation: R.S.Á., C.J., M.M.A. Methodology: R.S.Á., C.J., M.M.A. Project administration: M.M.A. Resources: C.J., A.W.P., J.C.P., C.I and M.M.A. Supervision: M.M.A. Validation: R.S.Á., C.J. and M.M.A. Visualization: R.S.Á. and M.M.A. Writing—original draft preparation: R.S.Á., and M.M.A. Writing-review and editing: C.J., F.S., J.C.P., A.W.P., C.I.

Funding: This study was supported by the National Agency for Promotion of Science and Technology 509 (ANPCYT-PICT 2017-0617) and the University of Buenos Aires (UBACYT-2018), (granted to María Marta 510 Amaral). It was also supported by the National Agency for Promotion of Science and Technology 511 (ANPCYT-PICT 12-0777) (granted to Cristina Ibarra) and National Scientific and Technical Research Council (CONICET PUE-2017-0041).

Acknowledgments: The authors wish to thank Horacio A Repetto, who died on January 7, 2019. "We would like to express our sincere gratitude for giving us his valuable guidance, suggestions and sharing his extensive experience as a pediatric nephrologist who attended so many children with HUS". We also are grateful to Roxane M. F. Piazza (Laboratorio de Bacteriología, Instituto Butantan, São Paulo, SP, Brasil) for kindly providing the monoclonal antibody 2E11 directed against the A-subunit of Stx2.

Conflicts of Interest: The authors declare no conflict of interest.

\section{References}

1. Karpman, D. Haemolytic uremic syndrome and thrombotic thrombocytopenic purpura. Curr. Paediatr. 2002, 12, 569-574. [CrossRef]

2. Karmali, M.A.; Petric, M.; Lim, C.; Fleming, P.C.; Arbus, G.S.; Lior, H. The association between idiopathic hemolytic uremic syndrome and infection by verotoxin-producing escherichia coli. J. Infect. Dis. 1985, 151, 775-782. [CrossRef] [PubMed]

3. Majowicz, S.E.; Scallan, E.; Jones-Bitton, A.; Sargeant, J.M.; Stapleton, J.; Angulo, F.J.; Yeung, D.H.; Kirk, M.D. Global incidence of human shiga toxin-producing escherichia coli infections and deaths: A systematic review and knowledge synthesis. Foodborne Pathog. Dis. 2014, 11, 447-455. [CrossRef] [PubMed]

4. Pianciola, L.; Rivas, M. Genotypic features of clinical and bovine escherichia coli o157 strains isolated in countries with different associated-disease incidences. Microorganisms 2018, 6, 36. [CrossRef]

5. Torres, A.G.; Amaral, M.M.; Bentancor, L.; Galli, L.; Goldstein, J.; Kruger, A.; Rojas-Lopez, M. Recent advances in shiga toxin-producing escherichia coli research in latin america. Microorganisms 2018, 6, 100. [CrossRef]

6. Rivas, M.; Chinen, I.; Miliwebsky, E.; Masana, M. Risk factors for shiga toxin-producing escherichia coli-associated human diseases. Microbiol. Spectr. 2014, 2. [CrossRef]

7. Argentina, SdPs MsdN. Boletín Integrado de Vigilancia; Secretaría de promoción y programas sanitarios. Ministerio de Salud de la Nación Argentina: Buenos Aires, Argentina, 2017; p. 352-SE.

8. Repetto, H.A. Epidemic hemolytic-uremic syndrome in children. Kidney Int. 1997, 52, 1708-1719. [CrossRef] 
9. Repetto, H.A. Microangiopatía trombótica y sindrome hemolítico urémico. Nefrol. Clínica 3ra Edición 2009, 6, 286-297.

10. Kruger, A.; Lucchesi, P.M. Shiga toxins and stx phages: Highly diverse entities. Microbiology 2015, 161, 451-462. [CrossRef]

11. Ibarra, C.; Amaral, M.M.; Palermo, M.S. Advances in pathogenesis and therapy of hemolytic uremic syndrome caused by shiga toxin-2. Iubmb. Life 2013, 65, 827-835. [CrossRef]

12. Golshani, M.; Oloomi, M.; Bouzari, S. In silico analysis of shiga toxins (stxs) to identify new potential vaccine targets for shiga toxin-producing escherichia coli. In Silico Pharmacol. 2016, 5, 2. [CrossRef] [PubMed]

13. Bai, X.; Fu, S.; Zhang, J.; Fan, R.; Xu, Y.; Sun, H.; He, X.; Xu, J.; Xiong, Y. Identification and pathogenomic analysis of an escherichia coli strain producing a novel shiga toxin 2 subtype. Sci. Rep. 2018, 8, 6756. [CrossRef] [PubMed]

14. Martin, C.C.; Svanevik, C.S.; Lunestad, B.T.; Sekse, C.; Johannessen, G.S. Isolation and characterisation of shiga toxin-producing escherichia coli from norwegian bivalves. Food Microbiol. 2019, 84, 103268. [CrossRef] [PubMed]

15. Rivas, M.; Miliwebsky, E.; Chinen, I.; Deza, N.; Leotta, G.A. The epidemiology of hemolytic uremic syndrome in argentina. Diagnosis of the etiologic agent, reservoirs and routes of transmission. Med. (B Aires) 2006, 66 (Suppl. 3), 27-32.

16. Fitzgerald, S.F.; Beckett, A.E.; Palarea-Albaladejo, J.; McAteer, S.; Shaaban, S.; Morgan, J.; Ahmad, N.I.; Young, R.; Mabbott, N.A.; Morrison, L.; et al. Shiga toxin sub-type 2a increases the efficiency of escherichia coli o157 transmission between animals and restricts epithelial regeneration in bovine enteroids. PLoS Pathog. 2019, 15, e1008003. [CrossRef] [PubMed]

17. Hussein, H.S. Prevalence and pathogenicity of shiga toxin-producing escherichia coli in beef cattle and their products. J. Anim. Sci. 2007, 85, E63-E72. [CrossRef] [PubMed]

18. Rivas, M.; Miliwebsky, E. Diagnóstico etiológico para establecer la asociación entre enfermedad humana e infección por Escherichia coli productor de toxina Shiga, cap 4. En Síndrome Urémico Hemolítico post-entérico. Actualización en patogénesis, diagnóstico y tratamiento del Síndrome Urémico Hemolítico asociado a la toxina Shiga. Editor. Acad. Esp. 2015, 4, 28-36.

19. Lingwood, C.A. Verotoxin/globotriaosyl ceramide recognition: Angiopathy, angiogenesis and antineoplasia. Biosci. Rep. 1999, 19, 345-354. [CrossRef]

20. Bergan, J.; Dyve Lingelem, A.B.; Simm, R.; Skotland, T.; Sandvig, K. Shiga toxins. Toxicon 2012, 60, $1085-1107$. [CrossRef]

21. Tesh, V.L. Activation of cell stress response pathways by shiga toxins. Cell Microbiol. 2012, 14, 1-9. [CrossRef]

22. Paton, A.W.; Srimanote, P.; Talbot, U.M.; Wang, H.; Paton, J.C. A new family of potent ab(5) cytotoxins produced by shiga toxigenic escherichia coli. J. Exp. Med. 2004, 200, 35-46. [CrossRef] [PubMed]

23. Galli, L.; Miliwebsky, E.; Irino, K.; Leotta, G.; Rivas, M. Virulence profile comparison between lee-negative shiga toxin-producing escherichia coli (stec) strains isolated from cattle and humans. Vet. Microbiol. 2010, 143, 307-313. [CrossRef] [PubMed]

24. Paton, J.C.; Paton, A.W. Shiga toxin 'goes retro' in human primary kidney cells. Kidney Int. 2006, 70, 2049-2051. [CrossRef] [PubMed]

25. Matsuura, G.; Morinaga, N.; Yahiro, K.; Komine, R.; Moss, J.; Yoshida, H.; Noda, M. Novel subtilase cytotoxin produced by shiga-toxigenic escherichia coli induces apoptosis in vero cells via mitochondrial membrane damage. Infect. Immun. 2009, 77, 2919-2924. [CrossRef] [PubMed]

26. May, K.L.; Paton, J.C.; Paton, A.W. Escherichia coli subtilase cytotoxin induces apoptosis regulated by host bcl-2 family proteins bax/bak. Infect. Immun. 2010, 78, 4691-4696. [CrossRef]

27. Wolfson, J.J.; May, K.L.; Thorpe, C.M.; Jandhyala, D.M.; Paton, J.C.; Paton, A.W. Subtilase cytotoxin activates perk, ire1 and atf6 endoplasmic reticulum stress-signalling pathways. Cell. Microbiol. 2008, 10, 1775-1786. [CrossRef]

28. Wang, H.; Paton, J.C.; Paton, A.W. Pathologic changes in mice induced by subtilase cytotoxin, a potent new escherichia coli ab5 toxin that targets the endoplasmic reticulum. J. Infect. Dis. 2007, 196, 1093-1101. [CrossRef]

29. Byres, E.; Paton, A.W.; Paton, J.C.; Lofling, J.C.; Smith, D.F.; Wilce, M.C.; Talbot, U.M.; Chong, D.C.; Yu, H.; Huang, S.; et al. Incorporation of a non-human glycan mediates human susceptibility to a bacterial toxin. Nature 2008, 456, 648-652. [CrossRef] 
30. Inoue, S.; Sato, C.; Kitajima, K. Extensive enrichment of n-glycolylneuraminic acid in extracellular sialoglycoproteins abundantly synthesized and secreted by human cancer cells. Glycobiology 2010, 20, 752-762. [CrossRef]

31. Lofling, J.C.; Paton, A.W.; Varki, N.M.; Paton, J.C.; Varki, A. A dietary non-human sialic acid may facilitate hemolytic-uremic syndrome. Kidney Int. 2009, 76, 140-144. [CrossRef]

32. Velandia, C.V.; Mariel Sanso, A.; Kruger, A.; Suarez, L.V.; Lucchesi, P.M.; Parma, A.E. Occurrence of subtilase cytotoxin and relation with other virulence factors in verocytotoxigenic escherichia coli isolated from food and cattle in argentina. Braz. J. Microbiol. 2011, 42, 711-715. [CrossRef] [PubMed]

33. Obrig, T.G. Escherichia coli shiga toxin mechanisms of action in renal disease. Toxins 2010, 2, $2769-2794$. [CrossRef] [PubMed]

34. Exeni, R.A.; Fernandez-Brando, R.J.; Santiago, A.P.; Fiorentino, G.A.; Exeni, A.M.; Ramos, M.V.; Palermo, M.S. Pathogenic role of inflammatory response during Shiga toxin-associated Hemolytic Uremic Syndrome (HUS). Pediatr. Nephrol. 2018, 33, 2057-2071. [CrossRef] [PubMed]

35. Repetto, H.A.; Rodríguez de Córdoba, S.; Arrizurieta, E.; Rivas, M.; Ibarra, C. Microangiopatía Trombótica y Síndrome Urémico Hemolítico. In Nefrología Clínica; Editorial médica panamericana; Ministerio de Salud de la Nación Argentina: Buenos Aires, Argentina, 2014; Cap 25 (351-363).

36. Richardson, S.E.; Karmali, M.A.; Becker, L.E.; Smith, C.R. The histopathology of the hemolytic uremic syndrome associated with verocytotoxin-producing escherichia coli infections. Hum. Pathol. 1988, 19, 1102-1108. [CrossRef]

37. Kaplan, B.S. Shiga toxin-induced tubular injury in hemolytic uremic syndrome. Kidney Int. 1998, 54, 648-649. [CrossRef]

38. Amaral, M.M.; Sacerdoti, F.; Jancic, C.; Repetto, H.A.; Paton, A.W.; Paton, J.C.; Ibarra, C. Action of shiga toxin type-2 and subtilase cytotoxin on human microvascular endothelial cells. PLOS ONE 2013, 8, e70431. [CrossRef]

39. Alvarez, R.S.; Sacerdoti, F.; Jancic, C.; Paton, A.W.; Paton, J.C.; Ibarra, C.; Amaral, M.M. Comparative characterization of shiga toxin type 2 and subtilase cytotoxin effects on human renal epithelial and endothelial cells grown in monolayer and bilayer conditions. PLOS ONE 2016, 11, e0158180. [CrossRef]

40. Valtin, H. Renal function: Mechanisms preserving fluid and solute balance in health and disease. In Renal Hemodynamics and Oxigen Consumption; Little, Brown and Company: Boston, MA, USA, 1973; Chapter 6.

41. Amigo, N.; Mercado, E.; Bentancor, A.; Singh, P.; Vilte, D.; Gerhardt, E.; Zotta, E.; Ibarra, C.; Manning, S.D.; Larzabal, M.; et al. Clade 8 and clade 6 strains of escherichia coli o157:H7 from cattle in argentina have hypervirulent-like phenotypes. PLoS ONE 2015, 10, e0127710. [CrossRef]

42. Pianciola, L.; D'Astek, B.A.; Mazzeo, M.; Chinen, I.; Masana, M.; Rivas, M. Genetic features of human and bovine escherichia coli o157:H7 strains isolated in argentina. Int. J. Med. Microbiol. 2016, 306, 123-130. [CrossRef]

43. Aydin, S.; Signorelli, S.; Lechleitner, T.; Joannidis, M.; Pleban, C.; Perco, P.; Pfaller, W.; Jennings, P. Influence of microvascular endothelial cells on transcriptional regulation of proximal tubular epithelial cells. Am. J. Physiol. Cell Physiol. 2008, 294, C543-C554. [CrossRef]

44. Bijuklic, K.; Jennings, P.; Kountchev, J.; Hasslacher, J.; Aydin, S.; Sturn, D.; Pfaller, W.; Patsch, J.R.; Joannidis, M. Migration of leukocytes across an endothelium-epithelium bilayer as a model of renal interstitial inflammation. Am. J. Physiol. Cell Physiol. 2007, 293, C486-C492. [CrossRef] [PubMed]

45. Guessous, F.; Marcinkiewicz, M.; Polanowska-Grabowska, R.; Kongkhum, S.; Heatherly, D.; Obrig, T.; Gear, A.R. Shiga toxin 2 and lipopolysaccharide induce human microvascular endothelial cells to release chemokines and factors that stimulate platelet function. Infect. Immun. 2005, 73, 8306-8316. [CrossRef] [PubMed]

46. Zoja, C.; Angioletti, S.; Donadelli, R.; Zanchi, C.; Tomasoni, S.; Binda, E.; Imberti, B.; te Loo, M.; Monnens, L.; Remuzzi, G.; et al. Shiga toxin-2 triggers endothelial leukocyte adhesion and transmigration via nf-kappab dependent up-regulation of il-8 and mcp-1. Kidney Int. 2002, 62, 846-856. [CrossRef] [PubMed]

47. Matussek, A.; Lauber, J.; Bergau, A.; Hansen, W.; Rohde, M.; Dittmar, K.E.; Gunzer, M.; Mengel, M.; Gatzlaff, P.; Hartmann, M.; et al. Molecular and functional analysis of shiga toxin-induced response patterns in human vascular endothelial cells. Blood 2003, 102, 1323-1332. [CrossRef] 
48. Brigotti, M.; Carnicelli, D.; Ravanelli, E.; Vara, A.G.; Martinelli, C.; Alfieri, R.R.; Petronini, P.G.; Sestili, P. Molecular damage and induction of proinflammatory cytokines in human endothelial cells exposed to shiga toxin 1, shiga toxin 2, and alpha-sarcin. Infect. Immun. 2007, 75, 2201-2207. [CrossRef]

49. Zoja, C.; Buelli, S.; Morigi, M. Shiga toxin-associated hemolytic uremic syndrome: Pathophysiology of endothelial dysfunction. Pediatr. Nephrol. 2010, 25, 2231-2240. [CrossRef]

50. Wang, H.; Rogers, T.J.; Paton, J.C.; Paton, A.W. Differential effects of escherichia coli subtilase cytotoxin and shiga toxin 2 on chemokine and proinflammatory cytokine expression in human macrophage, colonic epithelial, and brain microvascular endothelial cell lines. Infect. Immun. 2014, 82, 3567-3579. [CrossRef]

51. Lentz, E.K.; Leyva-Illades, D.; Lee, M.S.; Cherla, R.P.; Tesh, V.L. Differential response of the human renal proximal tubular epithelial cell line hk-2 to shiga toxin types 1 and 2. Infect. Immun. 2011, 79, 3527-3540. [CrossRef]

52. Galley, H.F.; Webster, N.R. Physiology of the endothelium. Br. J. Anaesth. 2004, 93, 105-113. [CrossRef]

53. Tasnim, F.; Zink, D. Cross talk between primary human renal tubular cells and endothelial cells in cocultures. Am. J. Physiol. Ren. Physiol. 2012, 302, F1055-F1062. [CrossRef]

54. Nee, L.E.; McMorrow, T.; Campbell, E.; Slattery, C.; Ryan, M.P. Tnf-alpha and il-1beta-mediated regulation of mmp-9 and timp-1 in renal proximal tubular cells. Kidney Int. 2004, 66, 1376-1386. [CrossRef] [PubMed]

55. Angelini, D.J.; Hyun, S.W.; Grigoryev, D.N.; Garg, P.; Gong, P.; Singh, I.S.; Passaniti, A.; Hasday, J.D.; Goldblum, S.E. Tnf-alpha increases tyrosine phosphorylation of vascular endothelial cadherin and opens the paracellular pathway through fyn activation in human lung endothelia. Am. J. Physiol. Lung Cell Mol. Physiol. 2006, 291, L1232-L1245. [CrossRef] [PubMed]

56. Goldblum, S.E.; Ding, X.; Campbell-Washington, J. Tnf-alpha induces endothelial cell f-actin depolymerization, new actin synthesis, and barrier dysfunction. Am. J. Physiol. 1993, 264, C894-C905. [CrossRef] [PubMed]

57. Beddoe, T.; Paton, A.W.; Le Nours, J.; Rossjohn, J.; Paton, J.C. Structure, biological functions and applications of the ab5 toxins. Trends Biochem. Sci. 2010, 35, 411-418. [CrossRef] [PubMed]

58. Rocha, L.B.; Luz, D.E.; Moraes, C.T.; Caravelli, A.; Fernandes, I.; Guth, B.E.; Horton, D.S.; Piazza, R.M. Interaction between shiga toxin and monoclonal antibodies: Binding characteristics and in vitro neutralizing abilities. Toxins 2012, 4, 729-747. [CrossRef]

59. Wang, H.; Paton, A.W.; McColl, S.R.; Paton, J.C. In vivo leukocyte changes induced by escherichia coli subtilase cytotoxin. Infect. Immun. 2011, 79, 1671-1679. [CrossRef]

60. Creydt, V.P.; Silberstein, C.; Zotta, E.; Ibarra, C. Cytotoxic effect of shiga toxin-2 holotoxin and its b subunit on human renal tubular epithelial cells. Microbes Infect. 2006, 8, 410-419. [CrossRef] 